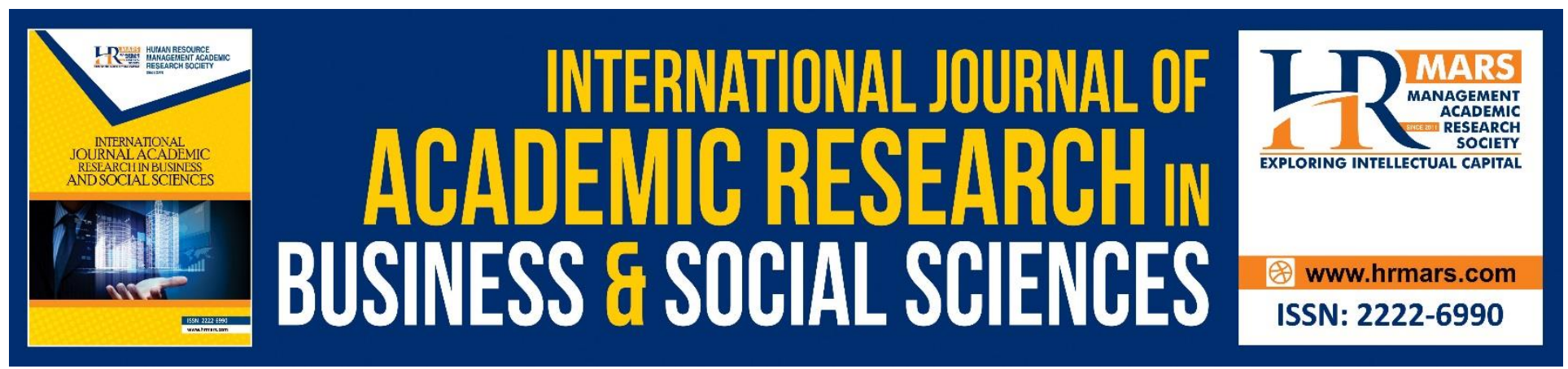

\title{
Acceptance of New Coconut Seed Matag Among Coconut Growers in Bagan Datoh, Perak And Bachok, Kelantan
}

\author{
Norsida Man \& Jasmin Arif Shah
}

To Link this Article: http://dx.doi.org/10.6007/IJARBSS/v10-i16/8286

DOI:10.6007/IJARBSS/v10-i16/8286

Received: 02 September 2020, Revised: 06 October 2020, Accepted: 30 October 2020

Published Online: 16 November 2020

In-Text Citation: (Man \& Shah, 2020)

To Cite this Article: Man, N., \& Shah, J. A. (2020). Acceptance of New Coconut Seed Matag Among Coconut Growers in Bagan Datoh, Perak And Bachok, Kelantan. International Journal of Academic Research in Business and Social Sciences, 10(16), 1-26.

\section{Copyright: (C) 2020 The Author(s)}

Published by Human Resource Management Academic Research Society (www.hrmars.com)

This article is published under the Creative Commons Attribution (CC BY 4.0) license. Anyone may reproduce, distribute, translate and create derivative works of this article (for both commercial and non-commercial purposes), subject to full attribution to the original publication and authors. The full terms of this license may be seen

at: http://creativecommons.org/licences/by/4.0/legalcode

Special Issue: Youth and Community Wellbeing: Issues, Challenges and Opportunities for Empowerment V2, 2020, Pg. 1 - 26 http://hrmars.com/index.php/pages/detail/IJARBSS JOURNAL HOMEPAGE

Full Terms \& Conditions of access and use can be found at http://hrmars.com/index.php/pages/detail/publication-ethics 


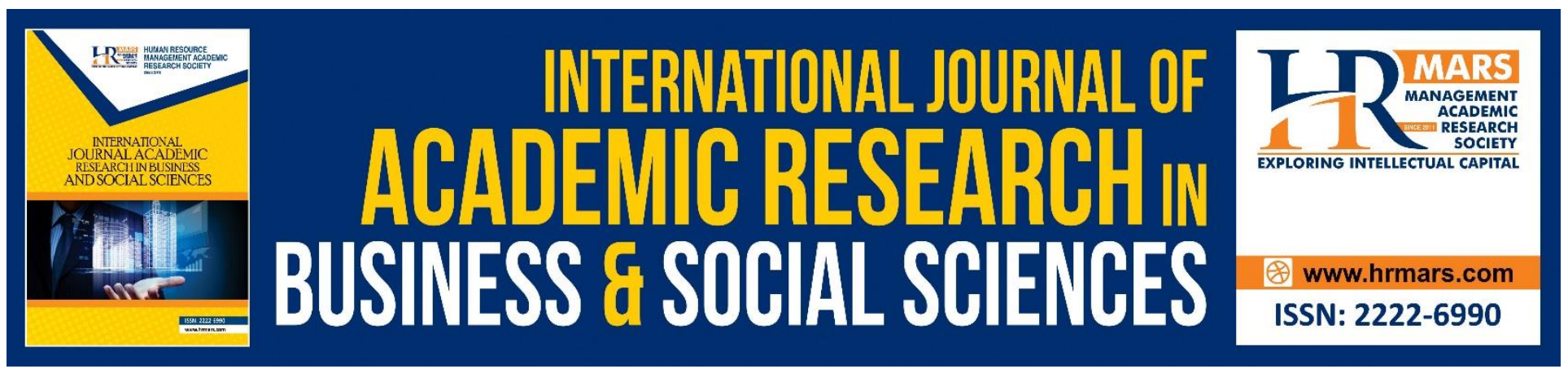

\title{
Acceptance of New Coconut Seed Matag Among Coconut Growers in Bagan Datoh, Perak And Bachok, Kelantan
}

\author{
Norsida Man ${ }^{1,2}$ \& Jasmin Arif Shah² \\ ${ }^{1}$ Social Science Studies Institute, Universiti Putra Malaysia, 43400 UPM, Serdang, Selangor, \\ Malaysia, ${ }^{2}$ Department of Agriculture Technology, Faculty of Agriculture, Universiti Putra Malaysia, \\ 43400 UPM, Serdang, Selangor, Malaysia. \\ Email: norsida@upm.edu.my,neojustmean@gmail.com
}

\begin{abstract}
Cocos nucifera is cultivated as a plantation crop in more than 90 countries for numerous purposes. It is native to coastal areas of Malaysia, Indonesia, Philippines, etc. The coconut plant has the greatest number of purposes, particularly in the tropics. The demand for coconut is strong; however, a low supply is limited by fewer farmers cultivating the new hybrid seed of MATAG, thereby resulting in a short ability to fulfil the demand of the coconut industry. Therefore, this study was undertaken with the primary aim to evaluate the acceptance factor of new coconut seed MATAG among coconut growers. Other objectives include to identify the knowledge and attitude level of coconut growers towards the new seed MATAG and to clarify the perception level of the agricultural extension activities in technology transfer of the new seed MATAG. A total of 100 respondents, each from Kelantan and Perak, were involved in this study. A questionnaire that consists of five (5) sections was distributed to the coconut growers. Data obtained were subjected to descriptive and mean ranking analysis using Statistical Package for Social Science (SPSS) version 25. The study finds that the respondents perceived the new coconut seed favorably. Although the attitude and knowledge level among coconut growers toward the new coconut seed is high, the extension agencies must enhance their commitment to transfer the knowledge and information on the new seed. In line with this finding, the study highlights the importance of the extension agencies as the crucial liaison to approach the farmers and the Ministry of Agriculture and Food-based Industry (MAFI) should provide training, disseminate improved technologies and support extension officers to assist the smallholder farmers. The farmers should also cooperate with the extension agents and the agricultural extension agencies should, in turn, encourage the farmers to actively involved in the coconut production as well as helping them to resolve the issues at the farm that are impeding the production.
\end{abstract}

Keywords: Coconut, Matag, Commercial Cultivation, Acceptance, Perception. 


\section{Coconut Palm Industry in Malaysia}

Coconut palm, or scientifically known as Cocos nucifera, is locally known as Kelapa or Nyior in Malaysia. It is a crop belonging to the palmea family that is thought to have originated in the Pacific Region. Each organ of the plant, from the roots, leaves, the stem to the nut, renders multifarious uses. In culinary, coconut milk is a staple ingredient in food preparation as well as a nutritional food product. Virgin Coconut Oil (VCO) is the new mainstream superfood highly sought by the public due to a myriad of health benefits. Non-food product from coconut, on the other hand, provides a source of building materials such roofing, planks, plywood, and fuel such as charcoal, firewood, etc.

There are numerous varieties of coconut used in cultivation such as Malaysia Tall (MT), Malaysia Red Dwarf (MRD), Malaysia Yellow Dwarf (MYD), Malaysia Green Dwarf (MGD), MAWA, MATAG, Pandan, West African Tall and Tagnanan. Coconut flourished in the rainforest and other tropical climates that are frost-free such as Africa, parts in Asia, Latin America and the Pacific Region. The plant is capable of thriving in a broad variety of soils, from mineral soil, bris soil to peat soil. More importantly, the trees favour coastal areas where the roots are afforded with plenty of moisture. Cultivation of the coconut tree requires at least a year to mature. The commercial output of coconut possesses high household values for an agricultural commodity that produced a wide variety of uses in the food and cosmetics industry.

Presently, Malaysia is one of the top 10 coconut producing countries in the world, topped by Indonesia as the world's largest producer. In 2014, Indonesia recorded a production area of 3.9 million ha that amounts to the productivity of 18 million metric tons (MT), followed by the Philippines and India with productivity area totaled at 3.2 million ha and 1.9 million ha, respectively. After oil palm, rubber and rice, coconut is Malaysia's fourth important industrial crop. In 2013, Malaysia recorded an increased in coconut production for both local and international markets from 550,140 (2010) to 624,727 MT. However, the production subsequently declined dramatically over the next three years from 2014 to 2016, with an estimated value of 530,000 MT. The main coconut producers in Malaysia are Johor, Perak, Sabah, Sarawak, and Selangor. In terms of socio-economy, the coconut industry contributes substantially to eradicate poverty with over 83,000 farming family are depending on the plant as a livelihood. The coconut production in the country composed of $74 \%$ of fresh coconut and $26 \%$ for the processing industry. According to Marina et al. (2006), Virgin Coconut Oil (VCO) is highly demanded in the industry because of the lauric acid content, which offers a wide range of health benefits, including enhancing digestibility and antiviral activity.

As of present, the production of the coconut remains inadequate to satisfy the industrial demands of both conventional and developing industries. The current production is still short of the current estimated demand of approximately $110,000 \mathrm{MT}$. The limited productivity is evidently attributed to the substantial declining in the acreage of cultivation area from 105,658 hectares in 2010 to 80,360 hectares in 2016. Apparently, growers are attracted to the prospect of earning lucratively from other more competitive crops, especially oil palm, hence the shift from coconut to the golden crop. Consequently, imports of coconut from a neighboring country are required in order to accommodate the local industrial demands. In 2014, Malaysia reportedly import coconut worth 63 million (2014). 
Therefore, the level of production must be enhanced in order to maximize the competitiveness of the local coconut industry. This would inevitably increase the profitability of income and stimulate the interests of coconut. To achieve the objective of improving the productivity of the local coconut industry, the Department of Agriculture has established several development programs, most notably involving the replanting and coconut estate recovery projects to expand the production area from 4,564 ha in the $8^{\text {th }}$ Malaysia Plan (MP) to 6,795 ha in the $9^{\text {th }}$ MP.

\section{1) Area Production of Coconut in Malaysia}

As an industry, coconut contributes relatively little to Malaysia's overall economy with an export value of approximately RM28,971 million in 2012. This is because coconut faces a stiff competition with the highly productive palm oil as evidenced by the substantial decline in the total area of cultivation from $100,996.01$ ha in 2012 to 82,917 ha in 2017 . According to projections under the $11^{\text {th }}$ MP, the demand for coconut by 2020 is expected to be 1.2 billion a year. Among the numerous coconut varieties, Malaysia cultivates the Malayan Tall as the predominant variety (92.2\%). Others include the $4.3 \%$ of hybrid MATAG, $1.7 \%$ of each MAWA and Pandan (1.7\%) and the Malayan Dwarfs constitutes a mere $0.2 \%$. Table 1 presents the distribution of the cultivation area of coconut in Malaysia and the production volume by the state in 2018. Johor has the largest cultivation area in Peninsular Malaysia with 12,949.7 ha, followed by Selangor 9,860.2 ha, Kelantan 9,542.1 ha and Perak $8,421.0$ ha. These four states have the highest productivity rates owing to the soil conditions and topography that are ideal for coconut cultivation. Even though both Sabah and Sarawak have a large production area, but the efficiency outputs are significantly lower compared to the four states in Peninsular Malaysia. 
INTERNATIONAL JOURNAL OF ACADEMIC RESEARCH IN BUSINESS AND SOCIAL SCIENCES

Vol. 10, No. 16, Youth and Community Wellbeing: Issues, Challenges and Opportunities for Empowerment V2. 2020, E-ISSN: 2222-6990 @ 2020 HRMARS

Table 1: Planted Area and Production of Coconut Crops by State, Malaysia (2018)

\begin{tabular}{|c|c|c|c|}
\hline \multirow[b]{2}{*}{ State } & \multicolumn{3}{|c|}{ Coconut } \\
\hline & $\begin{array}{l}\text { Planted } \\
\text { area } \\
\text { (ha) }\end{array}$ & $\begin{array}{l}\text { Harvested } \\
\text { area } \\
\text { (ha) }\end{array}$ & $\begin{array}{c}\text { Production } \\
\text { (tonnes) }\end{array}$ \\
\hline Johor & $12,949.7$ & $11,736.7$ & $95,495.7$ \\
\hline Kedah & 897.0 & 816.7 & $6,558.9$ \\
\hline Kelantan & 9,542.1 & $8,951.8$ & $73,676.0$ \\
\hline Melaka & $1,779.8$ & $1,689.9$ & $10,972.9$ \\
\hline $\begin{array}{l}\text { Negeri } \\
\text { Sembilan }\end{array}$ & $1,362.5$ & $1,185.3$ & $11,689.0$ \\
\hline Pahang & $4,321.8$ & $3,542.3$ & $27,059.0$ \\
\hline Perak & $8,421.0$ & $8,169.9$ & $69,966.3$ \\
\hline Perlis & 400.6 & 400.6 & $2,529.3$ \\
\hline $\begin{array}{l}\text { Pulau } \\
\text { Pinang }\end{array}$ & 37.0 & 33.0 & 227.8 \\
\hline Selangor & $9,860.2$ & 9309.7 & $95,641.5$ \\
\hline Terengganu & $4,064.9$ & 3480.5 & $20,607.0$ \\
\hline $\begin{array}{l}\text { Peninsular } \\
\text { Malaysia }\end{array}$ & $53,636.7$ & $49,316.4$ & $414,423.4$ \\
\hline Sabah & $16,968.4$ & $16,024.6$ & $50,477.5$ \\
\hline Sarawak & $13,258.7$ & $9,614.7$ & $30,113.5$ \\
\hline WP Labuan & 158.4 & 116.1 & 516.8 \\
\hline Malaysia & $84,022.2$ & $75,071.8$ & $495,531.1$ \\
\hline
\end{tabular}

Table 2 indicates the major area of coconut production with Bachok has the highest production volume of 45,359.8 tonnes, followed by Tumpat 13,060.8 tonnes, Kota Bharu 7,375.2 tonnes and Pasir Puteh 3,192.1 tonnes. The other districts in Kelantan are also involved in the production of coconut, albeit with lower production volume. Meanwhile, in Table 3, Hilir has the highest cultivation areas of coconut in Perak, which includes the areas of Bagan Datoh and Hutan Melintang. The total area cultivated was approximately 7,617.2 ha, yielding 63,364.9 tonnes of coconut. The official records of planting area and production volume for Bagan Datoh, however, is not available. 
INTERNATIONAL JOURNAL OF ACADEMIC RESEARCH IN BUSINESS AND SOCIAL SCIENCES

Vol. 10, No. 16, Youth and Community Wellbeing: Issues, Challenges and Opportunities for Empowerment V2. 2020, E-ISSN: 2222-6990 @ 2020 HRMARS

Table 2: Planted Area and Production of Industrial Crops by District in Kelantan (2018)

\begin{tabular}{cccc}
\hline & \multicolumn{3}{c}{ Coconut Planted in Kelantan } \\
\cline { 2 - 4 } District & $\begin{array}{c}\text { Planted } \\
\text { area } \\
\text { (ha) }\end{array}$ & $\begin{array}{c}\text { Harvested } \\
\text { area } \\
\text { (ha) }\end{array}$ & $\begin{array}{c}\text { Production } \\
\text { (Tonnes) }\end{array}$ \\
\hline Bachok & $\mathbf{6 , 2 2 7 . 3}$ & $\mathbf{5 , 9 3 4 . 2}$ & $\mathbf{4 5 , 3 5 9 . 8}$ \\
Gua & 9.0 & 5.0 & 68.0 \\
Musang & & & \\
Jeli & 58.6 & 57.9 & $\mathbf{7 6 2 . 3}$ \\
Kota Bharu & $\mathbf{1 , 0 2 6 . 5}$ & $\mathbf{9 7 1 . 5}$ & $\mathbf{7 , 3 7 5 . 2}$ \\
Kuala Krai & $\mathbf{9 1 . 3}$ & $\mathbf{5 4 . 6}$ & $\mathbf{4 7 6 . 4}$ \\
Machang & $\mathbf{1 9 7 . 3}$ & $\mathbf{1 6 0 . 8}$ & $\mathbf{1 3 0 9 . 1}$ \\
Pasir Mas & 166.3 & $\mathbf{5 4 . 1}$ & $\mathbf{8 9 6 . 3}$ \\
Pasir Puteh & $\mathbf{3 2 8 . 8}$ & $\mathbf{3 2 7 . 9}$ & $\mathbf{3 , 1 9 2 . 1}$ \\
Tanah & $\mathbf{2 7 4 . 0}$ & $\mathbf{2 6 5 . 5}$ & $\mathbf{1 , 1 7 6 . 2}$ \\
Merah & & & $13,060.8$ \\
Tumpat & $\mathbf{1 , 1 6 3 . 2}$ & $\mathbf{1 , 1 2 0 . 1}$ & $\mathbf{1 3 , 6}$ \\
\hline Total & $9,542.1$ & $8,951.8$ & $73,676.0$ \\
\hline
\end{tabular}

According to the statistics of the agro-food sector in 2018, Kelantan registered a total of 7,144 coconut growers, while Perak has 7,087. Table 4 compares the productivity rates between the coconut varieties of MATAG hybrid and Malayan Tall. The average output production of MATAG during the first six (6) years of the harvest is 18,467 nuts compared to 5,050 nuts of Malayan Tall. The data evidently suggests the grossly insufficient domestic supply of coconut to fulfil the growing demand in Malaysia, which is driven primarily by the rising population. The Department of Statistic Malaysia indeed revealed that Malaysia has expanded its population by $13 \%$ to 32 million in 2017. Furthermore, local consumption of coconut in 2006 increased from 506,000 tonnes to 510,000 in 2008 (Department of Agriculture, 2008; Tzotzou, 2014). Table 5 reports the average productivity of four coconut varieties, namely Malayan Tall, Malayan Dwarf, MATAG, and Pandan. Of the varieties, Malayan Tall has the lowest productivity with only 6,000-8,000 coconut per ha, a massive comparison with the other three varieties. Both Malayan Dwarf and Pandan varieties share a similar productivity rate with 27,000-30,000 coconut, compared to the relatively lower output from MATAG $(20,000$ $25,000)$. The difference may be attributed to the introduction of MATAG as the newest seed, which understandably requires more time to adapt to the environment.

\section{Price}

Table 6 reports the increased price of coconut between 2014 and 2015. In 2018, the retail price of coconut has risen to RM 2.00 to RM 2.50, with rates differing with the state and occasion i.e. the day of celebration. The rising population in Malaysia and the decline in coconut production are clearly affecting the price of coconut to increase every year. 
INTERNATIONAL JOURNAL OF ACADEMIC RESEARCH IN BUSINESS AND SOCIAL SCIENCES

Vol. 10, No. 16, Youth and Community Wellbeing: Issues, Challenges and Opportunities for Empowerment V2. 2020, E-ISSN: 2222-6990 @ 2020 HRMARS

Table 3: Planted Area and Production of Coconut by Districts in Perak (2018)

\begin{tabular}{rccc}
\hline District & $\begin{array}{c}\text { Planted } \\
\text { area (ha) }\end{array}$ & $\begin{array}{c}\text { Harvested } \\
\text { Area (ha) }\end{array}$ & $\begin{array}{c}\text { Production } \\
\text { (tonnes) }\end{array}$ \\
\hline Batang Padang & 97.2 & 61.9 & 519.9 \\
Hilir Perak & $7,617.2$ & $7,562.0$ & $63,364.9$ \\
Hulu Perak & 1.6 & 1.0 & 18.0 \\
Kampar & - & - & - \\
Kerian & 92.2 & 92.2 & 161.4 \\
Kinta & 105.8 & 47.0 & 890.0 \\
Kuala Kangsar & 15.5 & 14.6 & 220.7 \\
Larut Matang & 157.4 & 143.5 & $2,918.0$ \\
Selama & & & \\
Manjung & 309.4 & 223.5 & $1,540.6$ \\
Mualim & - & - & - \\
Perak Tengah & 24.8 & 24.2 & 332.8 \\
\hline Total & $8,421.0$ & $8,169.9$ & $69,966.3$ \\
\hline
\end{tabular}

Table 4: Productivity of Coconut Hybrid Compared with Malayan Tall

\begin{tabular}{|c|c|c|c|c|}
\hline \multirow{2}{*}{$\begin{array}{c}\text { Year } \\
\text { from } \\
\text { Planting }\end{array}$} & \multicolumn{2}{|c|}{ No. of Nuts/ha/year } & \multicolumn{2}{|c|}{ Copra/ha/year (Tonnes) } \\
\hline & MATAG & Malayan Tall & MATAG & Malayan Tall \\
\hline 4 & 9,600 & - & 2.40 & - \\
\hline 5 & 14,200 & 1,150 & 3.55 & 0.3 \\
\hline 6 & 21,000 & 3,850 & 5.25 & 1.0 \\
\hline 7 & 22,000 & 5,000 & 5.5 & 1.3 \\
\hline 8 & 18,000 & 6,900 & 4.5 & 1.8 \\
\hline 9 & 26,000 & 8,500 & 6.5 & 2.21 \\
\hline 10 & 27,600 & 9,200 & 6.9 & 2.39 \\
\hline 11 & 28,000 & 7,700 & 7.0 & 2.0 \\
\hline 12 & 29,200 & 9,300 & 7.3 & 2.42 \\
\hline 13 & 30,800 & 8,500 & 7.7 & 2.21 \\
\hline 14 & 28,000 & 9,300 & 7.0 & 2.42 \\
\hline 15 & 30,800 & 8,500 & 7.7 & 2.21 \\
\hline 16 & 28,000 & 9,300 & 7.0 & 2.42 \\
\hline 17 & 30,000 & 8,500 & 7.0 & 2.21 \\
\hline 18 & 28,000 & 9,300 & 7.5 & 2.42 \\
\hline 19 & 30,000 & 8,500 & 7.5 & 2.21 \\
\hline 20 & 28,000 & 9,300 & 7.0 & 2.42 \\
\hline $\begin{array}{l}\text { Mean } \\
\text { over } 1^{\text {st }} 6 \\
\text { years of } \\
\text { harvest }\end{array}$ & 18,467 & 5,080 & 4.62 & 1.32 \\
\hline $\begin{array}{l}\quad \text { Mean } \\
\text { over } 7-17 \\
\text { years of } \\
\text { harvest }\end{array}$ & 28,945 & 8,855 & 7.24 & 2.3 \\
\hline
\end{tabular}

Source: United Plantation Berhad, Teluk Intan, Perak 
Table 5: Average Productivity for Different Varieties of Coconut

\begin{tabular}{lc}
\hline Variety & Productivity (Number/Ha) \\
\hline Malayan Tall & $6,000-8,000$ \\
Malayan Dwarf & $27,000-30,000$ \\
MATAG & $20,000-25,000$ \\
Pandan & $27,000-30,000$ \\
\hline
\end{tabular}

Source: Department of Agriculture (2016)

Table 6: Price of Coconut (2014-2015)

\begin{tabular}{|c|c|c|c|c|c|c|c|}
\hline \multirow[b]{2}{*}{ Commodities } & \multirow[b]{2}{*}{ Grade } & \multicolumn{3}{|c|}{2014 (RM) } & \multicolumn{3}{|c|}{2015 (RM) } \\
\hline & & $\begin{array}{c}\text { Ex-farm } \\
\text { (100 nuts) }\end{array}$ & $\begin{array}{c}\text { Whole } \\
\text { sale (100 } \\
\text { nuts) } \\
\end{array}$ & $\begin{array}{c}\text { Retail } \\
\text { (1 } \\
\text { nut) }\end{array}$ & $\begin{array}{l}\text { Ex-farm } \\
\text { (100 nut) }\end{array}$ & $\begin{array}{c}\text { Whole } \\
\text { sale } \\
\text { (100 nuts) }\end{array}$ & $\begin{array}{l}\text { Retail } \\
\text { (1 nut) }\end{array}$ \\
\hline Shelled & Large & 110 & 145 & 1.85 & 115 & 150 & 1.95 \\
\hline \multirow[t]{3}{*}{ coconut } & Medium & 90 & 130 & 1.75 & 95 & 140 & 1.8 \\
\hline & Small & 80 & 110 & 1.35 & 85 & 115 & 1.35 \\
\hline & Not graded & 70 & 100 & 1.2 & 80 & 110 & 1.3 \\
\hline Young coconut & FAQ & 120 & 190 & 2.7 & 170 & 225 & 3.1 \\
\hline
\end{tabular}

Source: Federal Agricultural Marketing Authority

\section{3) Import and Export}

The government strongly encourages the cultivation coconut in order to meet the increasing demand for uses in cooking, baking, consumption, tourism activities and others. In 2015, Malaysia posted a trade deficit of RM 27,389,000 as the country exported coconut and coconut products valued at RM67,127,000 while importing RM 94,516,000 worth of coconut. Most of the export coconut comprised of coconut oil and coconut products such as activated carbon, dry grated coconut and coconut milk. The emergence of new products such as Virgin Coconut Oil further highlighted the importance of coconut.

\section{4) Varieties of Coconut}

Coconut palm is extensively cultivated in many tropical countries. It has become essential sources of food, drink, fibre, vitamins, minerals and electrolytes associated with remarkable health benefits. Presently, there are 12 distinct varieties of coconut in Malaysia, but only three hybrids are recommended by Department of Agriculture (DOA), which include Kelapa Wangi or Pandan (Aromatic Dwarf), MAWA and MATAG (DOA, 2011).

This study focuses on the MATAG cultivar, which is a hybrid of Malaysian Dwarf/Malayan Red Dwarf and the Philippines Tagnanan Tall. It is capable of yielding more coconut between 10 to 22 coconuts per time relative to other cultivars (Mohd. Taufik and Md. Akhir, 2014). Also, the hybrid begins fruiting in the third year of planting which can be harvested at 48 months (DOA, 2016). In terms of 
productivity rate, MATAG is relatively a high yielding variety compared to the common coconut or other hybrids with approximately 25,000-30,000 nuts per hectare per year (PRESSREADER, 2016).

\section{Problem Statement and Study Objective}

MATAG hybrid is a new coconut seed, a famous variety among local growers in Malaysia. The potential contribution of the new variety to the Malaysian economy remains unexplored, which accordingly presents an opportunity for a new business venture for farmers in the country. Considering the growing demands for raw material in cooking and the new functional food of Virgin Coconut Oil, the MATAG hybrid is identified as a suitable variety for commercial cultivation in several states of the major coconut producers in the country, most notably Johor, Perak, Selangor, Kelantan and Perak, owing to the favourable climate conditions.

This study seeks to address several issues that pertain the productivity of commercial cultivation of coconut in Malaysia. First, can the cultivation of MATAG hybrid achieve the maximum planting area in Malaysia to satisfy the future demand? It concerns with the long-term implication of importing fresh coconut from Indonesia to meet the consumers' demand towards the domestic industry. Second, there is currently a lack of infrastructure and technologies to facilitate coconut production. It begs the question on the sufficiency of the new seed. Third, farmers suffer from a lack of knowledge and practices on growing coconut, which could affect the production potential of the crop. Since MATAG is a relatively new hybrid, coconut growers must be informed on the physiological aspects of the plant. The country's aspiration to develop the industry that is capable of fulfilling the demand and achieve a decent supply of coconut would depend on the growers' acceptance of the MATAG variety.

The goal of this study is, therefore, to evaluate the acceptance of the new coconut seed among coconut growers. The study also aims to achieve the following specific objectives: 1) To identify respondents' profile; 2) To determine the knowledge and attitude level of respondents towards the new seed MATAG, and 3) To clarify the perception level of respondents toward the agricultural extension activities in transferring the technology of new seed MATAG.

\section{Literature Review}

Acceptance is defined as an individual's willingness and decision to adopt the innovation (Kotler, 1991). It is driven by the attitude of an individual on the use of technology and is influenced by several factors (Davis, 1989). To demonstrate how an individual accepts and adopts a technology or innovation, Davis (1989) proposes two scales viz perceived usefulness and perceived ease of use in the Technology Acceptance Model. Numerous researchers have attempted to identify and understand the factors that affect the users' acceptance by influencing the execution process in a way that reduces the resistance upon engaging the technology (Teo, 2011). Nazuri \& Man (2016) demonstrate that farmers perceive based on their experience with the new technology, however, it is not wise to assume that the farmers would characterize the technologies favourably. As a matter of fact, the education background and farmer's depth of knowledge affect the acceptance of the technology. Generally, the initial awareness upon the farmer's decision to accept and adopt the product involves a certain period from a mere couple of days to several years (Lionberger, 1960). This is where extension services play an essential role in relaying information on technology to the 
farmers. Knowledge of new seed varieties is a key factor in encouraging the adoption of technology and thereby, enhancing agricultural productivity among smallholders (Bekele et al., 2008).

Fundamentally, technology is an information body used to build resources, improve expertise and extract or acquire materials. It also makes use of adjustment and understanding of devices, software, crafts, systems and organizational practices to solve and develop a pre-existing approach to a problem, accomplish a goal, maintain the implemented input/output relation or execute a specific function (Liddell et al., 2000). It can also be described as a new, scientifically-derived, often nuanced input given to farmers by organizations with deep technological knowledge. Parvan (2010) also reiterates the view from Neill and Lee (2001) that the bulk of current literature on the adoption of agricultural technology focuses on Green Revolution (GR) innovations such as irrigation, fertilizer application, and the patterns of high-yield variety (HYV) seeds.

\section{Methodology}

The study was focusing on two (2) zones: West and East of Peninsular Malaysia. Hence, Perak and Kelantan were selected as location of study representing the states that are located in West and East Zone. The biggest of production area is Johor, however Perak was selected representing state located in West and Kelantan was selected representing the state from East Zone.

Multi-stage sampling was utilized in the selection of respondents. Specifically, the study was conducted in the districts of Bagan Datoh (Perak) and Bachok (Kelantan). Generally, the numbers of coconut growers from these districts are the highest in Perak and Kelantan. There are 7,087 and 7,144 coconut growers, respectively. A total of 200 respondents were selected from these two (2) districts, each 100 of respondents from Bagan Datoh (Perak) and Bachok (Kelantan). Data gathered from the study was subjected to descriptive and mean ranking analyses.

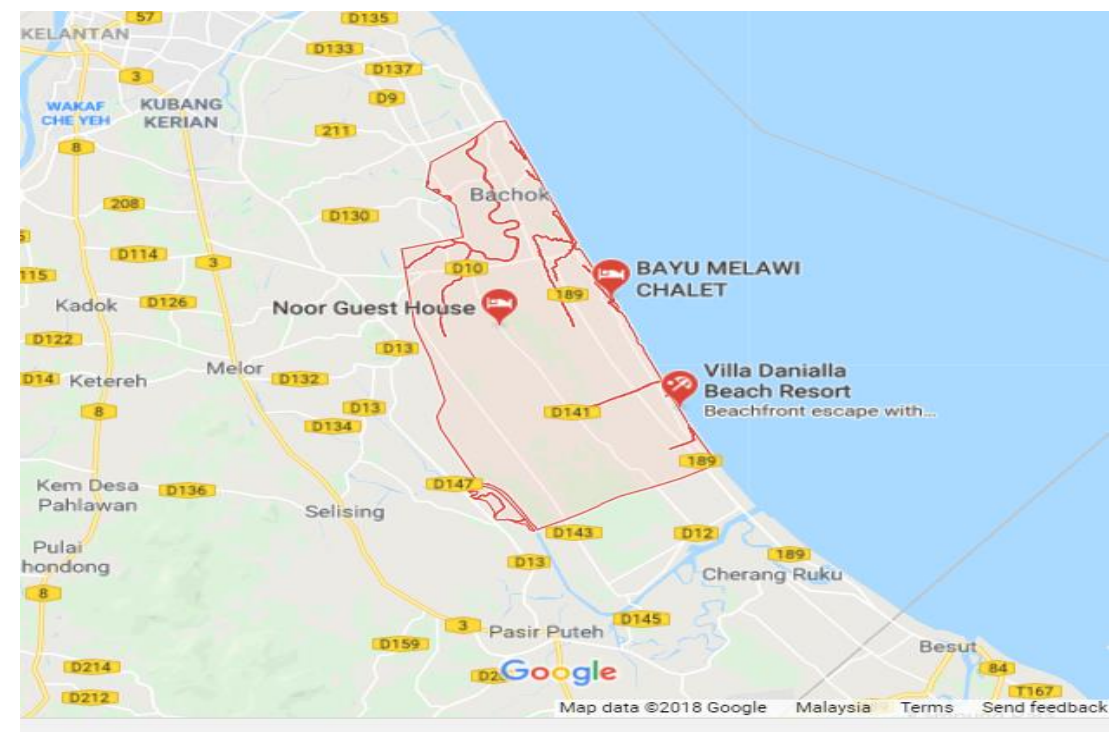

Figure 3.1: Map of Bachok District, Kelantan 


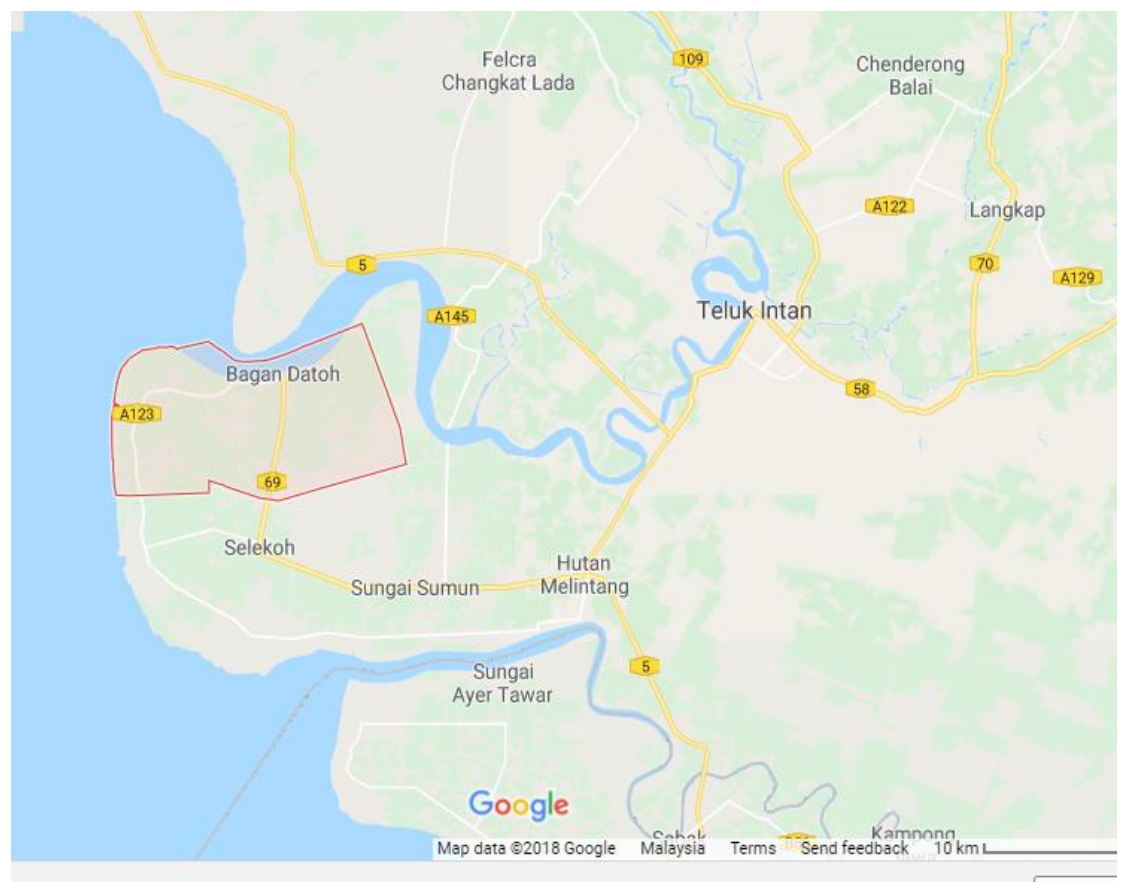

Figure 3.2: Maps of Bagan Datoh District, Perak

\section{Result and Discussion}

\section{1) Respondents' Demographic Profiles}

The respondents of this study are constituted by a diverse background. Table 7 categorized the age of the respondents. The respondents in Bachok comprised of $30 \%$ in the age range of $40-49,40 \%$ in between 50 to 59 years old. The older age ranges of $70-79$ and $80-89$ each constituted $8 \%$. On the contrary, older age of 70-79 constituted the majority of the growers in Bagan Datoh with $39 \%$. This is followed by the age range of 60-69 (33\%), middle-aged of 50-59 (12\%) and the oldest age range of 80-89 (9.0\%). The younger-aged farmers of $40-49$ constituted the least with $7.0 \%$.

Table 7: Age of Respondents ( $n=100$ for each state)

\begin{tabular}{ccccc}
\hline \multirow{2}{*}{ Age Category } & \multicolumn{2}{c}{ Bachok } & \multicolumn{2}{c}{ Bagan Datoh } \\
\cline { 2 - 5 } & Frequency & Percent (\%) & Frequency & Percent (\%) \\
\hline $40-49$ & 30 & 30.0 & 7 & 7.0 \\
$50-59$ & 40 & 40.0 & 12 & 12.0 \\
$60-69$ & 14 & 14.0 & 33 & 33.0 \\
$70-79$ & 8 & 8.0 & 39 & 39.0 \\
$80-89$ & 8 & 8.0 & 9 & 9.0 \\
\hline
\end{tabular}

In terms of gender, a large majority of the farmers in Bachok composed of male (83\%) and there were only $17 \%$ of female (Table 8). Interestingly, coconut farmers in Bagan Dato were largely predominated by the male $(92.0 \%)$, higher than male growers in Bachok. There were only $8.0 \%$ of female coconut growers participated in this study. 
Table 8: Gender of Respondents ( $\mathrm{n}=100$ for each state)

\begin{tabular}{lcccc}
\hline Gender & \multicolumn{2}{c}{ Bachok } & \multicolumn{2}{c}{ Bagan Datoh } \\
\cline { 2 - 5 } & Frequency & Percent (\%) & Frequency & Percent (\%) \\
\cline { 2 - 5 } Male & 83 & 83.0 & 92 & 92.0 \\
Female & 17 & 17.0 & 8 & 8.0 \\
\hline
\end{tabular}

Table 9 shows the racial composition of the respondents in Bachok and Bagan Datoh. Malay constituted predominantly among the growers in Bachok, followed by Siam and Chinese each constituted 3\%. Meanwhile, in Bagan Datoh, there were no Siam growers participated in this study with Malay as the large majority (95\%) and Chinese only 5\%.

Table 9: Races of Respondents ( $n=100$ for each state)

\begin{tabular}{lcccc}
\hline & \multicolumn{2}{c}{ Bachok } & \multicolumn{2}{c}{ Bagan Datoh } \\
\cline { 2 - 5 } Races & Frequency & Percent (\%) & Frequency & Percent (\%) \\
\hline Malay & 94 & 94.0 & 85 & 95.0 \\
Chinese & 3 & 3.0 & 15 & 5.0 \\
Siam & 3 & 3.0 & - & - \\
\hline
\end{tabular}

Table 10 described the education background of the respondents. In Bachok, $34 \%$ of the respondents comprised of SPM-level, followed by coconut growers who attended religious class (28\%), PMR-level (16\%), certificate/diploma educated (8\%) and each $7 \%$ of the respondents did not attend a school or at least attended Standard 6. In Bagan Datoh, on the contrary, the majority of the respondents attended religious class $(59 \%)$, followed by SPM-level (20\%). Coconut growers who attended Standard made up only $4 \%$ of the total respondents. The remaining respondents in Bagan Datoh comprised of $9 \%$ growers who did not attend school and $8 \%$ with PMR-level.

Table 10: Education Level of Respondents ( $n=100$ for each state)

\begin{tabular}{lcccc}
\hline \multirow{2}{*}{ Education Level } & \multicolumn{2}{c}{ Bachok } & \multicolumn{2}{c}{ Bagan Datoh } \\
\cline { 2 - 5 } & Frequency & Percent (\%) & Frequency & Percent (\%) \\
\hline Not Attend School & 7 & 7.0 & 9 & 9.0 \\
Religion Class & 28 & 28.0 & 59 & 59.0 \\
Standard 6 & 7 & 7.0 & 4 & 4.0 \\
SRP/PMR & 16 & 16.0 & 8 & 8.0 \\
SPM & 34 & 34.0 & 20 & 20.0 \\
Certificate/Diploma & 8 & 8.0 & - & - \\
\hline
\end{tabular}

Table 11 shows the percentage of respondents who have acquired agricultural education with only $1 \%$ from Bachok stated their attendance in the program distributed by the government or private agency. None of the respondents participated in this study from Bagan Datoh ever attended agricultural education. 
INTERNATIONAL JOURNAL OF ACADEMIC RESEARCH IN BUSINESS AND SOCIAL SCIENCES

Vol. 10, No. 16, Youth and Community Wellbeing: Issues, Challenges and Opportunities for Empowerment V2. 2020, E-ISSN: 2222-6990 @ 2020 HRMARS

Table 11: Education in Agriculture ( $n=100$ for each state)

\begin{tabular}{lcccc}
\hline \multicolumn{1}{c}{ Education in Agriculture } & \multicolumn{3}{c}{ Bachok } & \multicolumn{2}{c}{ Bagan Datoh } \\
\cline { 2 - 5 } & Frequency & Percent (\%) & Frequency & Percent (\%) \\
\cline { 2 - 5 } $\begin{array}{l}\text { Program Distribute by } \\
\begin{array}{l}\text { Government/Private } \\
\text { No }\end{array}\end{array}$ & 1 & 1 & - & - \\
\hline
\end{tabular}

Table 12 presented the respondent's occupation. In Bachok, the highest number of respondents is involved solely in coconut farming which is $39 \%$. Similarly, in Bagan Datoh, $66 \%$ of respondents focus solely on coconut farming. Respondents involved in coconut farming and other business accounted for $36 \%$ in Bachok and $15 \%$ in Bagan Datoh. Respondents involved in coconut and various crop and government/private sector in Bachok accounted for $15 \%$ and $10 \%$, respectively. Meanwhile, $19 \%$ of Bagan Datoh's respondents are involved in the farming of coconut and other crops.

Table 13 shows the percentage of respondent's experience in coconut farming. In Bachok, the highest frequency of farming experience with 15 years accounts for $44 \%$, followed by 10 years which is $40 \%$ of respondents. $8 \%$ of the respondents with more than 30 years of farming experience and only $5 \%$ of the respondents have at least 5 years of experiences. In Bagan Datoh, more than half of the respondents (66\%) have more than 30 years of experience in coconut farming, followed by 20 years, 10 years and 15 years which is $15 \%, 14 \%$ and $5 \%$, respectively.

Table 12: Occupation of Respondents ( $n=100$ for each state)

\begin{tabular}{lcccc}
\hline \multirow{2}{*}{ Occupation } & \multicolumn{2}{c}{ Bachok } & \multicolumn{2}{c}{ Bagan Datoh } \\
\cline { 2 - 5 } & Frequency & Percent (\%) & Frequency & Percent (\%) \\
\hline Coconut only & 39 & 39.0 & 66 & 66.0 \\
Coconut \& Other & 15 & 15.0 & 19 & 19.0 \\
Agriculture & & & & \\
Coconut \& Business & 36 & 36.0 & 15 & 15.0 \\
Coconut \& & 10 & 10.0 & - & - \\
Government/Private & & & & \\
\hline
\end{tabular}

Table 13: Experience of Respondents in Coconut Planting ( $n=100$ for each state)

\begin{tabular}{lcccc}
\hline Years & \multicolumn{2}{c}{ Bachok } & \multicolumn{2}{c}{ Bagan Datoh } \\
\cline { 2 - 5 } & Frequency & Percent (\%) & Frequency & Percent (\%) \\
\hline 5 & 2 & 2.0 & - & - \\
10 & 40 & 40.0 & 14 & 14.0 \\
15 & 44 & 44.0 & 5 & 5.0 \\
20 & 6 & 6.0 & 14 & 15.0 \\
30 and above & 8 & 8.0 & 15 & 66.0 \\
\hline
\end{tabular}


INTERNATIONAL JOURNAL OF ACADEMIC RESEARCH IN BUSINESS AND SOCIAL SCIENCES

Vol. 10, No. 16, Youth and Community Wellbeing: Issues, Challenges and Opportunities for Empowerment V2. 2020, E-ISSN: 2222-6990 @ 2020 HRMARS

\section{2) Respondents' Farm Profiles}

Table 14 shows the farming category. In Bachok, all of the respondents are individual farmers, whereas, in Bagan Datoh, $65 \%$ of the respondents are registered under agriculture agency and $35 \%$ of respondents are individual farmers.

Table 14: Farming Category ( $n=100$ for each state)

\begin{tabular}{lcccc}
\hline Farming Category & \multicolumn{2}{c}{ Bachok } & \multicolumn{2}{c}{ Bagan Datoh } \\
\cline { 2 - 5 } & Frequency & Percent (\%) & Frequency & Percent (\%) \\
\hline Individual & 100 & 100.0 & 35 & 35.0 \\
Under Agriculture & - & - & 65 & 65.0 \\
Agency & & & & \\
\hline
\end{tabular}

In terms of land ownership (Table 15), 100\% of the respondents in Bagan Datoh own their lands, whereas in Bachok, $97 \%$ of the respondents owned their own land and a mere 3\% rent and own land.

Table 15: Land Ownership ( $n=100$ for each state)

\begin{tabular}{lcccc}
\hline Land Category & \multicolumn{2}{c}{ Bachok } & \multicolumn{2}{c}{ Bagan Datoh } \\
\cline { 2 - 5 } & Frequency & Percent (\%) & Frequency & Percent (\%) \\
\hline Own & 97 & 97.0 & 100 & 100.0 \\
Own and Rental & 3 & 3.0 & - & - \\
\hline
\end{tabular}

In Table 16, 62\% of the coconut farms in Bachok are planted in a farm size of 0.5 ha and below, followed by 1 ha, 2 ha and 3 ha and beyond at 25\%,10\% and 3\%, respectively. In Bagan Datoh, 47\% of the respondents planted coconuts in 2 ha, followed by $36 \%$ in 3 ha and beyond. There is only $8 \%$ of the respondents planted coconut in 0.5 ha and below and $9 \%$ in 1 ha of land.

Table 17 shows the composition of the respondents' coconut growing stage. In Bachok, 75\% of the respondents indicated their trees are currently fruiting, while 19\% of the respondents indicated their coconut at the mature stage and fruiting. There is only $6 \%$ of the respondents has newly planted coconut trees but are already fruiting. In Bagan Datoh, $81 \%$ of the respondents indicated their coconut trees are fruiting whereas $19 \%$ of the respondents indicated their coconut at the mature stage and fruiting.

Table 16: Size of Land Area ( $n=100$ for each state)

\begin{tabular}{lcccc}
\hline Planted Area & \multicolumn{2}{c}{ Bachok } & \multicolumn{2}{c}{ Bagan Datoh } \\
\cline { 2 - 5 } (Ha) & Frequency & Percent (\%) & Frequency & Percent (\%) \\
\hline 0.5 ha and & 62 & 62.0 & 8 & 8.0 \\
below & & & & \\
1.0 ha & 25 & 25.0 & 9 & 9.0 \\
2.0 ha & 7 & 10.0 & 1 & 47 \\
3.0 and above & 3 & 3.0 & 15 & 36.0 \\
\hline
\end{tabular}


INTERNATIONAL JOURNAL OF ACADEMIC RESEARCH IN BUSINESS AND SOCIAL SCIENCES

Vol. 10, No. 16, Youth and Community Wellbeing: Issues, Challenges and Opportunities for Empowerment V2. 2020, E-ISSN: 2222-6990 @ 2020 HRMARS

Table 17: Growing Stage of Coconut ( $n=100$ for each state)

\begin{tabular}{lcccc}
\hline Growing Stage Category & \multicolumn{2}{c}{ Bachok } & \multicolumn{2}{c}{ Bagan Datoh } \\
\cline { 2 - 5 } & Frequency & Percent (\%) & Frequency & Percent (\%) \\
\hline Fruiting & 75 & 75.0 & 81 & 81.0 \\
Fruiting and Old Tree & 19 & 19.0 & 19 & 19.0 \\
New Planted Tree and & 6 & 6.0 & - & - \\
Fruiting & & & & \\
\hline
\end{tabular}

Table 18 shows the percentage of respondent's yield. In Bachok, the highest yield recorded by the respondents is around 400-600 number of coconuts, accounting for 52\% of the total responds obtained, followed by $601-800,1001-1200$, and $1201-1400$ coconut yield, accounting for $37 \%, 8 \%$ and 3\%, respectively. In Bagan Datoh, $53 \%$ of the respondents indicated their maximum yield of around $1401-1600$ of coconut, while $25 \%$ of the respondents produced around $801-1000$ coconut. The lowest yield around $601-800$ coconut accounted for $8 \%$ of the total responds obtained from Bagan Datoh.

In Table 19, 84\% of the respondents posted an income per season of around RM501- RM1,000. Meanwhile, $11 \%$ of the respondents earned around RM1,001-RM2,000 and $5 \%$ of the respondents posted the lowest income of RM500 and below. In Bagan Datoh, 81\% of the respondents earned higher around RM3,000 and above per season.

Table 18: Average Yield of Coconut Per Season in (Ha) of Land ( $n=100$ for each state)

\begin{tabular}{lcccc}
\hline Number of Coconut & \multicolumn{2}{c}{ Bachok } & \multicolumn{2}{c}{ Bagan Datoh } \\
\cline { 2 - 5 } & Frequency & Percent (\%) & Frequency & Percent (\%) \\
\hline $400-600$ & 52 & 52.0 & - & - \\
$601-800$ & 37 & 37.0 & 7 & 8.0 \\
$801-1000$ & - & - & 25 & 25.0 \\
$1001-1200$ & 8 & 8.0 & 1 & - \\
$1201-1400$ & 3 & 3.0 & 14 & 14.0 \\
$1401-1600$ & - & - & 52 & 53.0 \\
\hline
\end{tabular}

Table 19: Income Per Season for One Ha ( $\mathrm{n}=100$ for each state)

\begin{tabular}{lcccc}
\hline \multirow{2}{*}{$\begin{array}{c}\text { Income } \\
\text { (RM) }\end{array}$} & \multicolumn{2}{c}{ Bachok } & \multicolumn{2}{c}{ Bagan Datoh } \\
\cline { 2 - 5 } & Frequency & Percent (\%) & Frequency & Percent (\%) \\
\hline 500 and below & 5 & 5.0 & 1 & 1.0 \\
$501-1000$ & 84 & 84.0 & 13 & 13.0 \\
$1001-2000$ & 11 & 11.0 & 5 & 5.0 \\
3000 and above & - & - & 81 & 81.0 \\
\hline
\end{tabular}

Table 20 shows the distribution of coconut production. In Bachok, $59 \%$ of the respondents distributed the yield to coconut milk and coconut water sellers, $36 \%$ to coconut milk seller only and $5 \%$ to coconut water seller. In Bagan Datoh, the yields are predominantly distributed to coconut milk seller, 
wholesaler and factories, accounting for $75 \%$. The distribution of yield to coconut water seller only accounts for $14 \%$.

Table 21 described the varieties of coconut used for the planting. In Bachok, 52\% of the respondents planted Malayan Tall and MATAG coconut. There are $21 \%$ planted solely of Malayan tall variety. Others comprised of $2 \%$ planted mixed varieties of Malayan Tall and Pandan, and another $8 \%$ planted Pandan and MATAG varieties. None of the farmers in Bachok planted a sole MATAG variety of coconut at their farm. Compared to Bagan Datoh, $46 \%$ of the farmers planted solely of MATAG variety. Majority of the respondents (52\%) planted a mixed of the Malayan Tall and MATAG varieties, and only $2 \%$ of the respondents planted their farm with Malayan Tall and Pandan varieties.

Table 22 shows the sources of coconut seed. In Bachok, $42 \%$ of the respondents acquired the seed from Pasar Tani, followed by $29 \%$ from members and at Pasar Tani. Another $29 \%$ of the respondents obtained the seed from the Department of Agriculture (DOA) and Pasar Tani. Meanwhile, in Bagan Datoh, 51\% of the respondents acquired the seed from PPK, Department of Agriculture and Pasar Tani and 34\% of respondents obtained the seed from the Department of Agriculture and PPK. 9\% of the respondents obtained the source of seed solely from PPK.

Table 20: Distribution of Coconut Yield ( $n=100$ for each state)

\begin{tabular}{|c|c|c|c|c|}
\hline \multirow[t]{2}{*}{ Distribution } & \multicolumn{2}{|c|}{ Bachok } & \multicolumn{2}{|c|}{ Bagan Datoh } \\
\hline & Frequency & Percent (\%) & Frequency & Percent (\%) \\
\hline 1. Coconut Milk Seller & 36 & 36.0 & 14 & 14.0 \\
\hline 2. Coconut Water Seller & 5 & 5.0 & - & - \\
\hline $\begin{array}{l}\text { 3. Coconut Milk and } \\
\text { Water Seller }\end{array}$ & 59 & 59.0 & - & - \\
\hline 4. Coir Factory & - & - & 7 & 7.0 \\
\hline $\begin{array}{l}\text { 5. Coconut Milk and } \\
\text { Wholesaler }\end{array}$ & - & - & 4 & 4.0 \\
\hline $\begin{array}{l}\text { 6. Coconut Milk and } \\
\text { Wholesaler and } \\
\text { Factory }\end{array}$ & - & - & 75 & 75.0 \\
\hline
\end{tabular}


Table 21: Variety of Coconut Used for Planting ( $n=100$ for each state)

\begin{tabular}{lcccc}
\hline Coconut Variety & \multicolumn{2}{c}{ Bachok } & \multicolumn{2}{c}{ Bagan Datoh } \\
\cline { 2 - 5 } & Frequency & Percent (\%) & Frequency & Percent (\%) \\
\hline 1. Malayan Tall & 21 & 21.0 & - & - \\
2. Pandan & 5 & 5.0 & - & - \\
3. Malayan Tall and & 26 & 52.0 & 52 & 52.0 \\
$\quad$ MATAG & 22 & 2.0 & 2 & 2.0 \\
4. Malyan Tall and & & & & \\
$\quad$ Pandan & 8 & 8.0 & - & - \\
$\begin{array}{l}\text { 5. Pandan and MATAG } \\
\text { 6. Malayan Tall, Pandan }\end{array}$ & 17 & 17.0 & - & - \\
$\quad$ and MATAG & & - & & 46 \\
7. MATAG & - & & & 46.0 \\
\hline
\end{tabular}

Table 22: Source of Coconut Seed ( $n=100$ for each state)

\begin{tabular}{|c|c|c|c|c|}
\hline \multirow[t]{2}{*}{ Source of Seed } & \multicolumn{2}{|c|}{ Bachok } & \multicolumn{2}{|c|}{ Bagan Datoh } \\
\hline & Frequency & Percent (\%) & Frequency & Percent (\%) \\
\hline 1. Pasar Tani & 42 & 42.0 & - & - \\
\hline 2. PPK & - & - & 9 & 9.0 \\
\hline 3. PPK and Pasar Tani & - & - & 6 & 6.0 \\
\hline $\begin{array}{l}\text { 4. PPK, Department of } \\
\text { Agriculture and Pasar } \\
\text { Tani }\end{array}$ & - & - & 51 & 51.0 \\
\hline $\begin{array}{l}\text { 5. Department of } \\
\text { Agriculture and PPK }\end{array}$ & - & - & 34 & 34.0 \\
\hline $\begin{array}{l}\text { 6. Department of } \\
\text { Agriculture and Pasar } \\
\text { Tani }\end{array}$ & 6 & 29.0 & - & - \\
\hline $\begin{array}{l}\text { 7. Pasar Tani and } \\
\text { Members }\end{array}$ & 29 & 29.0 & - & - \\
\hline
\end{tabular}

Table 23 presents the problems faced by the respondents in Bachok and Bagan Datoh. In Bachok, the uneconomic and small size of land emerged as the major problem faced by the growers (20\%), followed by $19 \%$ complaining the unsystematic and conventional management practices. The respondents also suffer from the threats of pest and diseases (11\%); ageing and shortage of young people to assist in operational activities (14\%), and the diminished quality and performance of the coconut fruit after the second generation of planting (7\%). Interestingly, $11 \%$ indicated that they were untroubled by any of the issues. In Bagan Datoh, the major problem faced by the coconut growers is the threats from ape and wild boars from sustaining the coconut planting (31\%), followed by $14 \%$ indicated their challenges as a combination of one of several of the mentioned issues. Interestingly, $28 \%$ of the respondents indicated that they were untroubled by any of the issues at their farm. 
Table 23: Problems Faced by the Respondents in Coconut Farming

\begin{tabular}{|c|c|c|c|c|}
\hline \multirow[t]{2}{*}{ Issues } & \multicolumn{2}{|c|}{ Bachok } & \multicolumn{2}{|c|}{ Bagan Datoh } \\
\hline & Frequency & Percent (\%) & Frequency & Percent (\%) \\
\hline 1. Uneconomic and small land size. & 20 & 20.0 & 5 & 5.0 \\
\hline $\begin{array}{l}\text { 2. Pest and disease threats such as } \\
\text { attacks from palm red beetle. }\end{array}$ & 11 & 11.0 & 8 & 8.0 \\
\hline $\begin{array}{l}\text { 3. Unsystematic and conventional } \\
\text { practices and management, such } \\
\text { as lack of fertilization, and only } \\
\text { harvest fruit fallen from old trees. }\end{array}$ & 19 & 19.0 & 9 & 9.0 \\
\hline $\begin{array}{l}\text { 4. Existing coconut trees are mostly } \\
\text { tall coconut trees (Malayan Tall) } \\
\text { that are difficult to harvest. }\end{array}$ & 5 & 5.0 & - & - \\
\hline $\begin{array}{l}\text { 5. Energy incapacity due to ageing } \\
\text { factor and lack of young people to } \\
\text { assist in operating activities. }\end{array}$ & 14 & 14.0 & 5 & 5.0 \\
\hline $\begin{array}{l}\text { 6. Animal threats from apes and } \\
\text { wild boar present obstacles to } \\
\text { sustaining coconut planting. }\end{array}$ & - & - & 31 & 31.0 \\
\hline $\begin{array}{l}\text { 7. Diminished quality and } \\
\text { performance of the coconut fruit } \\
\text { after the second generation of } \\
\text { planting. }\end{array}$ & 7 & 7.0 & - & - \\
\hline $\begin{array}{l}\text { 8. More than one of the problems } \\
\text { presented above. }\end{array}$ & 13 & 13.0 & 14 & 14.0 \\
\hline 9. No problem. & 11 & 11.0 & 28 & 28.0 \\
\hline
\end{tabular}

\section{3) Respondents' Attitude and Knowledge towards New Coconut Seed MATAG}

\section{Knowledge on MATAG Coconut Seed}

Table 24 shows the respondent's knowledge of MATAG coconut seed. From the result, statement of "F2 production is not a pure MATAG seed" scored the highest mean which is 4.44 and the lowest mean is 4.19 with the statement "The hybrid of the MATAG coconut seed from (Dwarf x Tagnanan)". Table 25 shows the total average mean of 4.44, which is considered high-level knowledge possessed by the respondents of this study on new coconut seed MATAG. The high percentage is $88.5 \%$ of respondents have a high level of knowledge and only $11.5 \%$ respondents possessed a moderate level of knowledge. 
INTERNATIONAL JOURNAL OF ACADEMIC RESEARCH IN BUSINESS AND SOCIAL SCIENCES

Vol. 10, No. 16, Youth and Community Wellbeing: Issues, Challenges and Opportunities for Empowerment V2. 2020, E-ISSN: 2222-6990 @ 2020 HRMARS

Table 24: Respondents' Knowledge on New Coconut Seed MATAG

\begin{tabular}{|c|c|c|c|c|c|c|c|}
\hline \multirow{2}{*}{ Statement } & \multicolumn{5}{|c|}{ Frequency (\%) } & \multirow[t]{2}{*}{ Mean } & \multirow[t]{2}{*}{ S.D. } \\
\hline & 1 & 2 & 3 & 4 & 5 & & \\
\hline $\begin{array}{l}\text { 1. The hybrid of the MATAG coconut } \\
\text { seed from (Dwarf } x \text { Tagnanan) }\end{array}$ & - & - & $\begin{array}{c}39 \\
(19.5)\end{array}$ & $\begin{array}{c}79 \\
(39.5)\end{array}$ & $\begin{array}{c}82 \\
(41)\end{array}$ & 4.19 & 0.77 \\
\hline 2. Characteristic of MATAG tree & - & - & $\begin{array}{c}30 \\
(15)\end{array}$ & $\begin{array}{l}102 \\
(51)\end{array}$ & $\begin{array}{c}68 \\
(34)\end{array}$ & 4.22 & 0.68 \\
\hline 3. F2 is not a pure MATAG seed & - & - & - & $\begin{array}{c}113 \\
(56.5)\end{array}$ & $\begin{array}{c}87 \\
(43.5)\end{array}$ & 4.44 & 0.50 \\
\hline 4. High volume of coconut milk & - & - & $\begin{array}{c}41 \\
(20.5)\end{array}$ & $\begin{array}{c}73 \\
(36.5)\end{array}$ & $\begin{array}{c}86 \\
(43)\end{array}$ & 4.23 & 0.75 \\
\hline $\begin{array}{l}\text { 5. MATAG tree is better than other } \\
\text { varieties of the coconut tree }\end{array}$ & - & - & $\begin{array}{c}5 \\
(2.5)\end{array}$ & $\begin{array}{c}109 \\
(54.5)\end{array}$ & $\begin{array}{l}86 \\
(43)\end{array}$ & 4.41 & 0.54 \\
\hline $\begin{array}{l}\text { 6. MATAG starts flowering at about } \\
\text { 30-36 months after planting }\end{array}$ & - & - & $\begin{array}{l}16 \\
(8)\end{array}$ & $\begin{array}{c}101 \\
(50.5)\end{array}$ & $\begin{array}{c}83 \\
(41.5)\end{array}$ & 4.36 & 0.62 \\
\hline $\begin{array}{l}\text { 7. MATAG produces many fruits as } \\
25,000 \text { coconuts per year/ha }\end{array}$ & - & - & $\begin{array}{c}27 \\
(13.5)\end{array}$ & $\begin{array}{c}91 \\
(45.5) \\
\end{array}$ & $\begin{array}{c}82 \\
(41)\end{array}$ & 4.28 & 0.67 \\
\hline \multicolumn{6}{|c|}{ Total Average Mean } & 4.44 & 0.58 \\
\hline
\end{tabular}

Table 25: Level of Knowledge on New Coconut Seed MATAG

\begin{tabular}{|c|c|c|c|c|}
\hline Level & Frequency & Percent (\%) & Mean & S.D. \\
\hline Low (1-2.33) & - & - & \multirow{4}{*}{4.44} & \multirow{4}{*}{0.58289} \\
\hline Moderate (2.34-3.66) & 23 & 11.5 & & \\
\hline High (3.67-5) & 177 & 88.5 & & \\
\hline Total & 200 & 100 & & \\
\hline
\end{tabular}

\section{Attitude towards New Coconut Seed 'MATAG'}

Table 26 shows the result of the respondent's attitude towards new coconut seed MATAG. The statement of "I am sure that MATAG tree will reduce the cost of operation and management" have the highest mean, which is 4.88 and the lowest mean is 4.13 with the statement "I believe that planting MATAG seed will enhance the industry".

Table 27 shows the attitude level towards the new coconut seed of MATAG with a total mean of 4.53. The value indicates $100 \%$ of the respondents have a high attitude level towards the new coconut seed. 
INTERNATIONAL JOURNAL OF ACADEMIC RESEARCH IN BUSINESS AND SOCIAL SCIENCES

Vol. 10, No. 16, Youth and Community Wellbeing: Issues, Challenges and Opportunities for Empowerment V2. 2020, E-ISSN: 2222-6990 @ 2020 HRMARS

Table 4.23: Attitude Towards Acceptance on New Coconut Seed MATAG

\begin{tabular}{|c|c|c|c|c|c|c|c|}
\hline \multirow{2}{*}{ Statement } & \multicolumn{5}{|c|}{ Frequency (\%) } & \multirow[t]{2}{*}{ Mean } & \multirow[t]{2}{*}{ S.D. } \\
\hline & 1 & 2 & 3 & 4 & 5 & & \\
\hline $\begin{array}{l}\text { 1. I believe that planting } \\
\text { MATAG seed will } \\
\text { enhance the industry. }\end{array}$ & - & - & $\begin{array}{c}57 \\
(28.5)\end{array}$ & $\begin{array}{c}61 \\
(30.5)\end{array}$ & $\begin{array}{c}82 \\
(41)\end{array}$ & 4.13 & 0.83 \\
\hline $\begin{array}{l}\text { 2. I will make sure that I } \\
\text { plant the seed } \\
\text { immediately after the } \\
\text { seed is obtained. }\end{array}$ & - & - & $\begin{array}{c}2 \\
(1)\end{array}$ & $\begin{array}{c}78 \\
(39)\end{array}$ & $\begin{array}{l}120 \\
(60)\end{array}$ & 4.59 & 0.51 \\
\hline $\begin{array}{l}\text { 3. I am sure that MATAG } \\
\text { tree will reduce the cost } \\
\text { of operation and } \\
\text { management. }\end{array}$ & - & - & - & $\begin{array}{c}24 \\
(12)\end{array}$ & $\begin{array}{l}176 \\
(88)\end{array}$ & 4.88 & 0.33 \\
\hline $\begin{array}{l}\text { 4. I think that it is not } \\
\text { wrong to try and grow } \\
\text { MATAG seed. }\end{array}$ & - & - & $\begin{array}{c}3 \\
(1.5)\end{array}$ & $\begin{array}{c}81 \\
(40.5)\end{array}$ & $\begin{array}{l}116 \\
(58)\end{array}$ & 4.57 & 0.53 \\
\hline $\begin{array}{l}\text { 5. I am able to convince } \\
\text { other coconut growers to } \\
\text { plant MATAG seed. }\end{array}$ & - & - & - & $\begin{array}{c}43 \\
(21.5)\end{array}$ & $\begin{array}{c}157 \\
(78.5)\end{array}$ & 4.79 & 0.41 \\
\hline $\begin{array}{l}\text { 6. I believe that the quality } \\
\text { of MATAG coconut fruit } \\
\text { is better than the other } \\
\text { variety of coconut. }\end{array}$ & - & - & $\begin{array}{c}50 \\
(25)\end{array}$ & $\begin{array}{c}57 \\
(28.5)\end{array}$ & $\begin{array}{c}93 \\
(46.5)\end{array}$ & 4.22 & 0.82 \\
\hline \multicolumn{6}{|c|}{ Total Average Mean } & 4.53 & 0.42 \\
\hline
\end{tabular}

Table 4.24: Attitude Level towards New Coconut Seed MATAG

\begin{tabular}{lcccc}
\hline Level & Frequency & Percent (\%) & Mean & S.D. \\
\hline Low (1-2.33) & - & - & & \\
Moderate (2.34-3.66) & - & - & & \multirow{2}{*}{4.53} \\
High (3.67-5) & 200 & 100 & & 0.42 \\
\cline { 1 - 4 } Total & $\mathbf{2 0 0}$ & $\mathbf{1 0 0}$ & & \\
\hline
\end{tabular}

\section{4) Perception toward the New Coconut Seed of MATAG}

Table 28 presents the respondents' perceptions of the new seed of coconut. Five of the six statements - new seed guarantees coconut supply, a new seed is necessary for cultivation, MATAG coconut seed can reduce the difficulty in farm activities, a new seed is crucial in the coconut industry to meet the consumers' demand and the new seed will help farmers improve their product efficiency, scored a mean value of 4.64 . The lowest mean (4.53) of the statement "New seed of MATAG coconut is important for effective field production". 
Table 28: Respondents' Perception toward New Coconut Seed

\begin{tabular}{|c|c|c|c|c|c|c|c|}
\hline \multirow{2}{*}{ Statement } & \multicolumn{5}{|c|}{ Frequency (\%) } & \multirow[t]{2}{*}{ Mean } & \multirow[t]{2}{*}{ S.D. } \\
\hline & 1 & 2 & 3 & 4 & 5 & & \\
\hline $\begin{array}{l}\text { 1. New seed is important for effective } \\
\text { field production. }\end{array}$ & - & - & $\begin{array}{c}1 \\
(0.5)\end{array}$ & $\begin{array}{c}92 \\
(46)\end{array}$ & $\begin{array}{c}107 \\
(53.5)\end{array}$ & 4.53 & 0.51 \\
\hline $\begin{array}{l}\text { 2. The quality of MATAG coconut seed } \\
\text { guarantees the supply of coconut in } \\
\text { the country. }\end{array}$ & - & - & $\begin{array}{c}1 \\
(0.5)\end{array}$ & $\begin{array}{c}70 \\
(35)\end{array}$ & $\begin{array}{c}129 \\
(64.5)\end{array}$ & 4.64 & 0.49 \\
\hline $\begin{array}{l}\text { 3. New seed is a necessity in } \\
\text { cultivation. }\end{array}$ & - & - & $\begin{array}{c}1 \\
(0.5)\end{array}$ & $\begin{array}{c}71 \\
(35.5)\end{array}$ & $\begin{array}{l}128 \\
(64)\end{array}$ & 4.64 & 0.49 \\
\hline $\begin{array}{l}\text { 4. I believe the use of a new seed of } \\
\text { MATAG coconut can reduce the } \\
\text { difficulty in farm activities. }\end{array}$ & - & - & $\begin{array}{c}1 \\
(0.5)\end{array}$ & $\begin{array}{c}71 \\
(35.5)\end{array}$ & $\begin{array}{l}128 \\
(64)\end{array}$ & 4.64 & 0.49 \\
\hline $\begin{array}{l}\text { 5. New seed is crucial in the coconut } \\
\text { industry to meet the consumer's } \\
\text { demand. }\end{array}$ & - & - & $\begin{array}{c}1 \\
(0.5)\end{array}$ & $\begin{array}{c}71 \\
(35.5)\end{array}$ & $\begin{array}{l}128 \\
(64)\end{array}$ & 4.64 & 0.49 \\
\hline $\begin{array}{l}\text { 6. New coconut seed will help farmers } \\
\text { to improve their production } \\
\text { efficiency. }\end{array}$ & - & - & $\begin{array}{c}1 \\
(0.5)\end{array}$ & $\begin{array}{c}70 \\
(35)\end{array}$ & $\begin{array}{c}129 \\
(64.5)\end{array}$ & 4.64 & 0.49 \\
\hline \multicolumn{6}{|c|}{ Total Average Mean } & 4.62 & 0.48 \\
\hline
\end{tabular}

Table 29 shows the result of the opinion level of the respondents towards technology in new coconut seed. The total mean of 4.62 is the maximum with $99.5 \%$ of the respondents indicated their acceptance toward the technology and while the remaining $5 \%$ indicated a moderate acceptance.

Table 29: Perception Level on the Acceptance of Technology in New Coconut Seed

\begin{tabular}{lcccc}
\hline Level & Frequency & Percent (\%) & Mean & S.D. \\
\hline Low (1-2.33) & - & - & & \\
Moderate (2.34-3.66) & 1 & 5 & & \\
High (3.67-5) & 199 & 99.5 & 4.62 & 0.48 \\
Total & 200 & 100 & & \\
\hline
\end{tabular}

\section{5) Respondents' Engagement in Agricultural Extension Activities on New Coconut Seed}

Table 30 shows 100\% of the respondents in Bagan Datoh involved in PPK activities. Meanwhile, in Bachok, 54\% of the respondents were involved with the Department of Agriculture (DOA) whereas the remaining $46 \%$ did not involve in any agricultural agency. Table 31 shows the frequency of communication between agricultural agencies and coconut growers. In Bagan Datoh, 100\% respondents were contacted by the agricultural agency at least once per year. In Bachok, on the other hand, $44 \%$ of the respondents did not receive any contact from the agency. $38 \%$ of respondents stated that the agency contacted them around once per two years and $3 \%$ of respondents was contacted around once per year. 
Table 30: Agricultural Agencies Involvement ( $n=100$ for each state)

\begin{tabular}{lcccc}
\hline \multicolumn{1}{c}{ Entertained Agencies } & \multicolumn{2}{c}{ Bachok } & \multicolumn{2}{c}{ Bagan Datoh } \\
\cline { 2 - 5 } & Frequency & Percent (\%) & Frequency & Percent (\%) \\
\hline Pertubuhan Peladang Kawasan & - & - & 100 & 100.0 \\
(PPK) & & & & \\
Department of Agriculture (DOA) & 54 & 54.0 & - & - \\
Not Involved & 46 & 46.0 & - & - \\
\hline
\end{tabular}

Table 31: Frequency of Communication by Agricultural Agencies ( $n=100$ for each state)

\begin{tabular}{lcccc}
\hline \multirow{2}{*}{ Times Involved } & \multicolumn{2}{c}{ Bachok } & \multicolumn{2}{c}{ Bagan Datoh } \\
\cline { 2 - 5 } & Frequency & Percent (\%) & Frequency & Percent (\%) \\
\hline Once per Year & 3 & 3.0 & 100 & 100.0 \\
Once in Two Years & 38 & 38.0 & - & - \\
Don't have & 44 & 44.0 & - & - \\
Others & 15 & 15.0 & - & - \\
\hline
\end{tabular}

Based on the result presented in Table 32, a relatively high percentage of the respondents indicated that they were not involved in any of the activities conducted by the agricultural agency. $23 \%$ of respondents have involved in fertilizer and farm management. In Bagan Datoh, majority of the respondents (66\%) reported their active participation in all of the activities conducted by the agricultural agency.

Table 33 shows the respondent's frequency of involving in activities conducted by the agricultural agency. In Bachok, the highest percentage of $37 \%$ of the respondents indicated their involvement once in every two years. $25 \%$ of respondents stated their involvement only once in three years and the rest did not involve in any of the activities. In Bagan Datoh, $85 \%$ of the respondents indicated their involvement once in every two years and $15 \%$ of respondents were involved once in a year.

Table 34 presents the respondents' perception of agricultural agencies and extension activities. The highest mean is 4.52 with the statement "Agricultural agencies are friendly and able to communicate with easy language to transfer information". The lowest mean is 3.50 with the statement "Agricultural agencies help to market my agricultural product". 
INTERNATIONAL JOURNAL OF ACADEMIC RESEARCH IN BUSINESS AND SOCIAL SCIENCES

Vol. 10, No. 16, Youth and Community Wellbeing: Issues, Challenges and Opportunities for Empowerment V2. 2020, E-ISSN: 2222-6990 @ 2020 HRMARS

Table 32: Respondents' Involvement in Activities Conducted by the Agricultural Agency ( $n=100$ for each state)

\begin{tabular}{lcccc}
\hline Activities & \multicolumn{2}{c}{ Bachok } & \multicolumn{2}{c}{ Bagan Datoh } \\
\cline { 2 - 5 } & Frequency & Percent (\%) & Frequency & Percent (\%) \\
\hline 1. Farm management & 4 & 4.0 & - & - \\
2. Field trip & 19 & 19.0 & - & - \\
3. Fertilizer and Farm & 23 & 23.0 & 19 & 19.0 \\
$\quad$ Management & & & & \\
4. Fertilizer, Farm and & 2 & 2.0 & 15 & 15.0 \\
$\quad$ Data Management & & & & \\
5. Fertilizer and Disease & 11 & 11.0 & - & - \\
$\quad$ Control & & & & \\
6. All the above & 4 & 4.0 & 65 & 66 \\
7. Not Involved & 37 & 37.0 & - & - \\
\hline
\end{tabular}

Table 33: Respondents' Frequency Involved in Activities Conducted by Agricultural Agency

\begin{tabular}{lcccc}
\hline \multirow{2}{*}{ Frequency of Involvement } & \multicolumn{2}{c}{ Bachok } & \multicolumn{2}{c}{ Bagan Datoh } \\
\cline { 2 - 5 } & Frequency & Percent (\%) & Frequency & Percent (\%) \\
\hline Once per Year & - & - & 15 & 15.0 \\
Once in Every Two Years & 37 & 37.0 & 85 & 85.0 \\
Once in Over Three Years & 25 & 25.0 & - & - \\
Not Involved & 38 & 38.0 & - & - \\
\hline
\end{tabular}


INTERNATIONAL JOURNAL OF ACADEMIC RESEARCH IN BUSINESS AND SOCIAL SCIENCES

Vol. 10, No. 16, Youth and Community Wellbeing: Issues, Challenges and Opportunities for Empowerment V2. 2020, E-ISSN: 2222-6990 @) 2020 HRMARS

Table 34: Perception of the Activities Performed by Agricultural Agencies

\begin{tabular}{|c|c|c|c|c|c|c|c|}
\hline \multirow{2}{*}{ Statement } & \multicolumn{5}{|c|}{ Frequency (\%) } & \multirow[t]{2}{*}{ Mean } & \multirow[t]{2}{*}{ S.D. } \\
\hline & 1 & 2 & 3 & 4 & 5 & & \\
\hline $\begin{array}{l}\text { 1. Agriculture agencies carry out their } \\
\text { duties fairly and effectively. }\end{array}$ & $\begin{array}{c}38 \\
(19)\end{array}$ & - & $\begin{array}{c}37 \\
(18.5)\end{array}$ & $\begin{array}{c}41 \\
(20.5)\end{array}$ & $\begin{array}{c}84 \\
(42)\end{array}$ & 3.67 & 1.49 \\
\hline $\begin{array}{l}\text { 2. Activities organized by agricultural } \\
\text { agencies are matching farmer's time. }\end{array}$ & - & - & $\begin{array}{l}38 \\
(19)\end{array}$ & $\begin{array}{c}62 \\
(31)\end{array}$ & $\begin{array}{l}102 \\
(51)\end{array}$ & 4.47 & 0.57 \\
\hline $\begin{array}{l}\text { 3. The implemented programs have a } \\
\text { positive impact on farmers and can } \\
\text { solve the problem faced by the farmers. }\end{array}$ & - & $\begin{array}{c}1 \\
(0.5)\end{array}$ & $\begin{array}{c}37 \\
(18.5)\end{array}$ & $\begin{array}{c}61 \\
(30.5)\end{array}$ & $\begin{array}{c}101 \\
(50.5)\end{array}$ & 4.31 & 0.79 \\
\hline $\begin{array}{l}\text { 4. Agricultural agencies help and monitor } \\
\text { my farm. }\end{array}$ & - & - & $\begin{array}{c}53 \\
(26.5)\end{array}$ & $\begin{array}{c}47 \\
(23.5)\end{array}$ & $\begin{array}{l}100 \\
(50)\end{array}$ & 4.24 & 0.79 \\
\hline $\begin{array}{l}\text { 5. Agriculture agencies help to market my } \\
\text { agricultural product. }\end{array}$ & $\begin{array}{c}2 \\
(1)\end{array}$ & $\begin{array}{c}1 \\
(0.5)\end{array}$ & $\begin{array}{c}93 \\
(46)\end{array}$ & $\begin{array}{l}104 \\
(52)\end{array}$ & - & 3.50 & 2.17 \\
\hline $\begin{array}{l}\text { 6. Agricultural agencies plan all programs } \\
\text { and activities in sequence. }\end{array}$ & $\begin{array}{c}2 \\
(1)\end{array}$ & $\begin{array}{c}6 \\
(3)\end{array}$ & $\begin{array}{l}92 \\
(46)\end{array}$ & $\begin{array}{c}19 \\
(9.5)\end{array}$ & $\begin{array}{c}81 \\
(40.5)\end{array}$ & 3.86 & 0.92 \\
\hline $\begin{array}{l}\text { 7. The number of agricultural agencies is } \\
\text { sufficient in my area. }\end{array}$ & - & - & $\begin{array}{c}63 \\
(31.5)\end{array}$ & $\begin{array}{c}137 \\
(68.5)\end{array}$ & - & 3.67 & 1.03 \\
\hline $\begin{array}{l}\text { 8. Agriculture agencies have extensive } \\
\text { skills and knowledge in delivering } \\
\text { information and technology. }\end{array}$ & - & - & $\begin{array}{c}85 \\
(42.5)\end{array}$ & $\begin{array}{c}30 \\
(15)\end{array}$ & $\begin{array}{c}85 \\
(42.5)\end{array}$ & 4.0 & 0.84 \\
\hline $\begin{array}{l}\text { 9. Agriculture agencies are friendly and } \\
\text { able to communicate with easy } \\
\text { language to transfer information. }\end{array}$ & & & $\begin{array}{c}37 \\
(18.5)\end{array}$ & $\begin{array}{c}22 \\
(11)\end{array}$ & $\begin{array}{c}141 \\
(70.5)\end{array}$ & 4.52 & 0.47 \\
\hline
\end{tabular}

Total Average Mean

$4.03 \quad 0.76$

Table 33 presents the respondents' perception level towards agricultural agencies and their extension activities. The total mean of 4.03 can be considered as high. There were $74.5 \%$ of the respondents perceived highly towards the activities performed by the agricultural agencies. $25 \%$ of the respondents, on the other hand, perceived moderately.

Table 35: Perception Level Towards Agricultural Agencies and Activities of Extension Programme

\begin{tabular}{lcccc}
\hline Level & Frequency & Percent (\%) & Mean & S.D. \\
\hline Low (1-2.33) & - & - & & \\
Moderate (2.34-3.66) & 51 & 25.5 & & \multirow{2}{*}{4.03} \\
High (3.67-5) & 149 & 74.5 & & \\
\cline { 1 - 3 } Total & $\mathbf{2 0 0}$ & $\mathbf{1 0 0}$ & & \\
\hline
\end{tabular}

\section{Conclusion and Recommendation}

From the descriptive analysis, the majority of the coconut growers involved in this study were male for both districts of Bachok and Bagan Datoh. The growers are between 50 to 89 years of age. The farmers are predominantly Malay by race, with only 3-5\% of the growers are Chinese. Most of them 
have been involved in coconut farming for more than 10 years, while some have experience of more than 30 years. Most of the coconut yield in Bachok is sold to coconut milk and coconut water seller, whereas farmers in Bagan Datoh sell their coconut mainly to wholesaler and factory that produces Virgin Coconut Oil.

In Bachok, planting of the coconut using MATAG variety is relatively low compared to Bagan Datoh where the farmers also plant in combination with Malayan Tall variety of coconut. In Bachok, most of the farmers have a planting area of less than 1 ha. In comparison, the planting areas in Bagan Datoh consist of a land size around 2ha-3ha and beyond. Coconut growers in Bagan Datoh earn higher than in Bachok because the farmers focus mainly on farming coconut. Farmers in Bachok reported coconut farming as a side income.

From the result, the respondents perceived highly towards the new coconut seed. According to them, MATAG variety has a positive effect on development and economic life. They also believed that the hybrid could enhance their income and that the operational management of the coconut hybrid, particularly during harvesting, would also be easier.

Furthermore, the extension agent has played a great role in easing technology acceptance among coconut growers. Considering their level of expertise, the extension agents know more than the farmers. While the farmers only know about the release of the new seed, they do not, however, know any more about the values as well as its benefits. Therefore, the extension agents play a key role in the transition of modern seed technology to farmers. They must be able to convince the farmers to adopt the new seed of MATAG. That is, the adoption of new seed is necessary if the farmers want to increase their yield and maintain the farm easily.

\section{Recommendation}

The Department of Agriculture (DOA), particularly in Kelantan, has a major role to play in assisting the farmers to manage their coconut farm and most of the farmers rely on DOA for guidance towards becoming a successful farmer. Yet, the study found that DOA never visited the farm and supplies of MATAG seed in Kelantan are difficult to procure. Furthermore, the farmers also expressed their disappointments at the quality of the seed procured from "Pasar Tani" where the production efficiency falls short of the expectation, i.e. low yield. Their responses should be taken into consideration into future extension service planning. Acceptance of new seed will have an effect on their potential as coconut producer as it could improve the productivity and farm management efficiency.

Meanwhile, in Bagan Datoh, the main agency, namely Pertubuhan Peladang Kawasan (PPK), seemed committed to doing their job, but it is the case that depends on the farmers to accept new seed. This happened because the farmers are severely limited in their energy capacity because of the ageing factor in doing the heavy work. Rehabilitation planting activities have already been undertaken by PPK in Bagan Datoh with offers to manage the farmer's coconut farm. The farmers, in turn, should trust the staffs (PPK) to take over the farm's management. Regardless, the extension officers should 
provide frequent training on the use of improved technologies, such as the use of fertilizer and pesticides, in order to increase coconut yields.

Finally, the government under the Ministry of Agriculture and Food-based Industry should provide the training, disseminate the improved technologies and fully support the extension officers and smallholder farmers. The government must ensure the accessibility of agricultural inputs to the farmers that include fertilizers and improved seedlings. In order to ensure the new seed of MATAG is accepted by the farmers, all parties should play their roles. It is essential to note that, the role of extension is the most important liaison where effective extension activities would encourage farmers willingness to accept the new seed of coconut.

\section{References}

Arts, J. W. C., Frambach, R. T., \& Bijmolt, T. H. A. (2011). Generalizations on consumer innovation adoption: A meta-analysis on drivers of intention and behaviour. International Journal of Research in Marketing, 28(2): 134-144.

Davis, F. (1989). Perceived Usefulness, Perceived Ease of Use, and User Acceptance of Information Technology. MIS Quarterly, 13(3): 319-340.

DOA. (2017). Booklet Statistik Tanaman. Sub- Sektor Tanaman Makanan.

DOSM. (2018) Anggaran Penduduk Semasa Malaysia, 2017-2018.

Doss, C. (2003). Understanding Farm- level Technology Adoption: Lesson Learned from CIMMYT's Micro Survey in Eastern Africa. Economic Working Paper No. 03-07, CIMMYT, Mexico: 26.

Gollwitzer, P. (1999). Implementation Intention. Strong Effects of Simple Plans USA, 54(7): 493-503.

Liddell, A., George, H., \& Scott, R. (2000). A Greek-English Lexicon (Abridged Edition). United Kingdom: Oxford University Press, UK: 168.

Lopes, H. (2010). Adoption of Improved Maize and Common Bean Varieties in Mozambique. Dissertation for Award of MARD degree at Sokoine University of Agriculture, Morogoro, Tanzania: 115.

Mitropoulos, P., \& Tatum, C. (2000). Forces Driving Adoption of New Information Technologies. Journal of Construction Engineering and Management, 126 (5): 340-348.

Nazuri, N. S., \& Man, N. (2016). Acceptance and practices on new paddy seed variety among farmers in MADA granary area. Academic Journal of Interdisciplinary Studies, 5(2): 105-105.

Neill, S., \& Lee, D. (2001). Explaining the Adoption and Disadoption of Sustainable Agriculture: The Case of Cover Crops in Northern Honduras. Working Paper No.31, Department of Agricultural, Resource, and Managerial Economics, Cornell University, USA: 27.

PRESSREADER. (2016). Hybrid coconut: Its potential to help overcome poverty. Retrieved from https://www.pressreader.com/philippines/.

Rogers, E. (2003). Diffusion of Innovations (5th Ed). The Free Press Publishers, New York, USA: 551.

Selvarajah, V., \& Geretharan, T. (2013). Factors that influence the adoption of improved coconut management practices in Batticaloa District. Proceedings of the Third International Symposium, Oluvil, Sri Lanka: 4.

Tzotzou, M. D. (2014). Designing A Set of Procedures for The Conduct of Peer Observation in the Efl Classroom: A Collaborative Training Model Towards Teacher Development. Multilingual Academic Journal of Education and Social Sciences, 2(2), 16-29. 
INTERNATIONAL JOURNAL OF ACADEMIC RESEARCH IN BUSINESS AND SOCIAL SCIENCES

Vol. 10, No. 16, Youth and Community Wellbeing: Issues, Challenges and Opportunities for Empowerment V2. 2020, E-ISSN: 2222-6990 @ 2020 HRMARS

Teo, T. (2011). Technology acceptance research in education. In Technology acceptance in education. SensePublishers: 5. 